Revta brasil. Bot., São Paulo, V.24, n.2, p.167-172, jun. 2001

\title{
Reproductive biology of the protandrous Ferdinandusa speciosa Pohl (Rubiaceae) in southeastern Brazil
}

\author{
CIBELE CARDOSO DE CASTRO ${ }^{1}$ and \\ PAULO EUGÊNIO ALVES MACEDO DE OLIVEIRA ${ }^{2,3}$
}

(received: July 4, 2000; accepted: January 31, 2001)

\begin{abstract}
Reproductive biology of the protandrous Ferdinandusa speciosa Pohl (Rubiaceae) in southeastern Brazil). A study of the floral biology and the breeding system of Ferdinandusa speciosa Pohl (Rubiaceae) was carried out from March to September 1996 in Uberlândia, MG, central Brazil. This species is a shrub or small tree that occurs in swampy edges of gallery forests. The two studied populations flowered somewhat asynchronously from March to July. The tubular flowers are red, approximately $4.7 \mathrm{~cm}$ long and last for two days. They are protandrous and the pollen is available one day before the stigma becomes receptive. The beginning of anthesis and the opening of the stigmatic lips occur at dusk. The nectar is secreted during both the male and the female phases, with concentration of sugars greater in the male phase. The flowers are pollinated by two hummingbird species, Chlorostilbon aureoventris and Phaethornis pretrei. Ferdinandusa speciosa is a self-compatible, non-apomictic species, with low fruit production under natural conditions in the populations studied. No differences were found between fruit set of self- and cross-pollinated flowers, nor in the pollen tube growth rate in the pistils of these flowers. The seeds formed by cross-pollination are larger, heavier and show a higher percentage of germination than those formed by self-pollination, which indicates inbreeding depression. This result suggests that, although the species is self-compatible, cross-pollination may be advantageous.
\end{abstract}

RESUMO - (Biologia reprodutiva de Ferdinandusa speciosa Pohl (Rubiaceae), uma espécie protândrica do sudeste brasileiro). O estudo da biologia floral e sistema de reprodução de Ferdinandusa speciosa Pohl (Rubiaceae) foi realizado durante os meses de março a setembro de 1996 em Uberlândia, MG, Brasil central. Esta espécie é uma arvoreta que ocorre em margens alagadas de matas de galeria. As populações estudadas floresceram de março a julho, apresentando pulsos de emissão de inflorescências que conferiram uma certa assincronia de floração tanto individual quanto populacional. As flores possuem corola vermelha, tubular, levemente curvada, medindo cerca de $4,7 \mathrm{~cm}$ de comprimento e duram dois dias. São protândricas, e a oferta de pólen precede em um dia a receptividade estigmática. Tanto o início da antese quanto a abertura dos lábios estigmáticos ocorrem no crepúsculo. O néctar está disponível nas fases masculina e feminina, apresentando maior concentração de açúcares na fase masculina. As flores são polinizadas por duas espécies de beija-flor, Chlorostilbon aureoventris e Phaethornis pretrei. Ferdinandusa speciosa é uma espécie autocompatível, não apomítica e com baixa produção de frutos em condições naturais. Não houve diferença significativa entre a produção de frutos formados por autopolinização e polinização cruzada, nem na taxa de crescimento de tubos polínicos provenientes destes dois tipos de cruzamento. As sementes formadas por polinização cruzada são maiores, com massa e taxa de germinação maiores do que as formadas por autopolinização, indicando que, embora a espécie seja autocompatível, a polinização cruzada é vantajosa.

Key words - Ferdinandusa, hummingbird, pollination, protandry, Rubiaceae

\section{Introduction}

The family Rubiaceae shows a great variety of breeding systems (Bawa \& Beach 1983) and pollination syndromes, including butterfly (Hamilton 1990), moth (Nilsson et al. 1990), bee (Hamilton 1990) and bird pollination (Sobrevilla $e t$ al. 1983, Castro \& Araújo, unpublished data, Ree 1997). The three subfamilies (sensu Bremer 1996) show three main reproductive mechanisms:

1. Universidade Estadual de Campinas, Depto. Botânica, Caixa Postal 6109, 13083-970 Campinas, SP, Brazil.

2. Universidade Federal de Uberlândia, Instituto de Biociências, Rua Duque de Caxias, 285, Caixa Postal 593, 38400-902 Uberlândia, MG, Brazil.

3. Corresponding author: cibelecastro@ hotmail.com heterostyly is more common in Rubioideae, secondary pollen presentation on the style in Ixoroideae, whereas Cinchonoideae presents both mechanisms; anemophily is restricted to more advanced tribes of Rubioideae (Robbrecht 1988). All these mechanisms are relatively constant within the tribes (Robbrecht 1988). However, these trends were inferred from limited samples and for some species they seem to be difficult to apply (e.g. Imbert $\&$ Richards 1993). Additional studies are needed to support if these trends are consistent and if so try to explain their occurrence.

The genus Ferdinandusa Pohl (Cinchoneae) comprises 23 neotropical species occurring from Central America to southeastern Brazil (Andersson 1993). F. speciosa Pohl is a shrub distributed in south western Amazon (Peru, Bolivia and Brazil); in 
Brazil this species also occurs in the central and southeastern cerrados (Andersson 1993), generally in swampy edges of gallery forests. The objectives of this study are to describe the pollination biology and breeding system of $F$. speciosa in south-central Brazil, and compare the results with the general patterns of reproductive mechanisms suggested for Rubiaceae.

\section{Material and methods}

We studied two populations of Ferdinandusa speciosa Pohl (Rubiaceae) in Uberlândia (Central Brazil, 18 ${ }^{\circ} 55^{\prime} \mathrm{S}$ and $48^{\circ} 17^{\prime} \mathrm{W}$ and $c a .800 \mathrm{~m}$ alt.) occurring in gallery forest fragments, in areas altered by human activities and subjected to flooding during the rainy season (Dec-Mar). Fertile individuals were shrubs and small trees 1-6 m high. Our study was conducted between March and September 1996.

A total of 20 flowers from ten individuals were monitored from anthesis to flower abscission. Pollen viability was estimated in four individuals, four buds each (three anthers per bud), using the aceto-carmine staining technique (Radford et al. 1974), under a microscope. Stigmatic receptivity was determined through the peroxidase activity technique (Kearns \& Inouye 1993), between 05:45 and 18:00 h (two hours intervals), in both floral phases $(\mathrm{n}=20$, from eight individuals). Buds in pre-anthesis stage $(\mathrm{n}=10$, from eight individuals) were also tested for stigmatic receptivity. Floral morphology data were obtained from fixed material (FAA 50\%) collected in both male and female phases. Lengths of the corolla, stamen filament and style, and corolla diameter were measured with a calliper (error: $0.01 \mathrm{~mm}$ ) on a sample of picked flowers (days 1 and $2, \mathrm{n}=40$ ) from $c a .20$ individuals. Pollen/ovule ratio (sensu Cruden 1977) was calculated by counting all pollen grains (stained by aceto carmine) from a half of a thecae of anthers from three flowers, and all the ovules from six pistils; in both cases one flower was used per plant, and the observation made under a microscope.

Nectar volume and sugar concentration were measured on 21 bagged flowers from 15 individuals, using calibrated glass capillaries and hand refractometer (Dafni 1992). The values on the refractometer were considered as sucrose equivalents (sensu Inouye et al. 1980). These data were collected approximately at 11:00 $\mathrm{h}$ on the first day of anthesis (male phase) and at the same time on the second day (female phase) for the same flowers $(n=6)$. The nectar of another set of bagged flowers $(n=15)$ was collected at 11:00 $\mathrm{h}$ on the second day, representing accumulated values. Nectar secretion was also checked on buds and at the beginning of anthesis. Values of nectar volume and concentration were compared with a Student t-test.

Floral visitors and their behavior were recorded from 05:45 h until 21:00 $\mathrm{h}$, for a total of $48 \mathrm{~h}$ of focal observation. The hole period was sampled with the same effort, but on different days. Pollinators were determined based on frequency of visits and the visiting behavior (observation of legitimate visits and contact with floral sexual organs). Photos were taken for the identification of the hummingbirds (following Grantsau 1989). Measurements of hummingbirds were obtained from museum specimens from the Museu de História Natural da Universidade Estadual de Campinas (ZUEC).

Hand pollination treatments were done using flowers on female phase, from 22 individuals, between 10:00 h to 11:00 h. The flowers were bagged during pre-anthesis stage with nylon mesh bags and were not emasculated (except in apomixis experiments), and inflorescences received more than one kind of treatment. Pollen transfer was performed contacting the open anther with a receptive stigma, using a fine forceps to hold the anther filament. Self-pollinations $(\mathrm{n}=35)$ and cross-pollinations $(\mathrm{n}=32)$ using non-neighbour plants were performed, and differences on fruit set between these treatments were determinated using a Chi-square test. Emasculations in pre-anthesis floral buds were done to test for the presence of apomixis $(n=46)$. Open flowers were tagged to test fruit set under natural conditions $(\mathrm{n}=54)$.

Fruits and seeds resulting from self- and cross-pollination experiments were compared with the Kruskal-Wallis test, using the number and weight of the fruits and the number, length (major axis including the wings) and weight of the seeds; germination rate was compared with a Student t-test. The germination experiment was undertaken using 60 seeds resulted from each reproductive experiment (self- and cross- pollination). The seeds were kept in plastic dishes with sand (sterilized at $180^{\circ} \mathrm{C}$ for $48 \mathrm{~h}$ ) in a greenhouse and monitored daily until the protrusion of the radicule.

Pollen tube growth rates resulting from self- and cross-pollinations were investigated using the fluorescence technique (adapted from Martin 1959) in pistils fixed 24, 48 and $72 \mathrm{~h}$ after hand pollination. Fruits of 21 individuals were counted to estimate the individual fruit set. Voucher specimens of the plants were deposited in the herbarium of Universidade Federal de Uberlândia (HUFU 13092).

\section{Results}

The flowering period of Ferdinandusa speciosa Pohl spans from March to July, its start coinciding with the end of the rains and the beginning of the dry season. The species apparently presented emission of inflorescences in pulses, which resulted in flowering asynchrony within and between individuals. Inflorescences are terminal and flowers are pendent, tetramerous, sympetalous, sinsepalous and epigynous, with a nectariferous disk at the base of floral tube. An individual presents from 4 to 20 inflorescences with 2 to 70 flowers each one.

Floral biology and morphometrics - The flowers are hermaphrodite, protandrous and last for two days. Anthesis began at dusk and flowers were completely open before dawn. The male phase comprised the first day of anthesis, when the pollen was released but the stigmatic lips were closed and unreceptive (figure 1). The stigmatic lips started to open at dusk on the first day and receptivity was observed from 

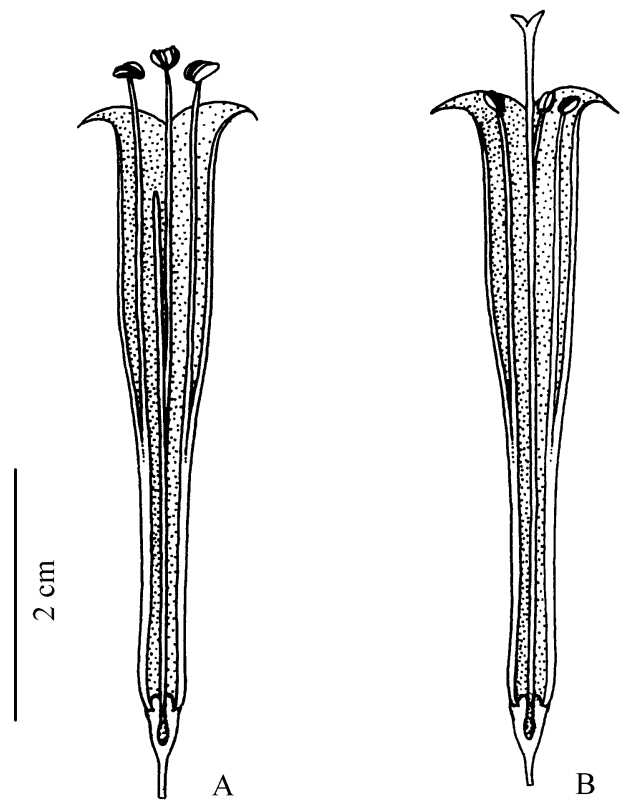

Figure 1. Flowers of Ferdinandusa speciosa in male (A) and female (B) phases.

05:45 $\mathrm{h}$ on until dusk of the second day, when the corolla falls off. The only significant morphometric difference between the male and female phases was the decrease of the stamen filaments length (table 1).

Pollen viability was $81.9 \pm 5.7 \%(x \pm S E, n=16$ flowers). Most individuals presented differences in pollen viability between flowers (from 50 to $80 \%$ ). A flower produced a mean of $34672 \pm 4260$ pollen grains ( $x \pm S E, n=3$ flowers) and $31.6 \pm 3.2$ ovules ( $x \pm S E, n=6$ flowers). The pollen-ovule ratio was $1.1 \times 10^{-3}$.

Table 1. Morphometric data $(\mathrm{x} \pm \mathrm{SE}, \mathrm{cm})$ of Ferdinandusa speciosa flowers in male and female phases. Legend: CoL corolla length; $\mathrm{D}^{\mathrm{max}}$ and $\mathrm{D}^{\mathrm{min}}$ maximum and minimum corolla diameters, respectively; Ft total stamen filament length. The asterisk indicates significant differences.

\begin{tabular}{lcl}
\hline Atribute & Male (n) & Female (n) \\
\hline CoL & $4.8 \pm 0.10(12)$ & $4.7 \pm 0.1(10)$ \\
$\mathrm{D}^{\max }$ & $0.7 \pm 0.04(12)$ & $0.7 \pm 0.0(10)$ \\
$\mathrm{D}^{\min }$ & $0.3 \pm 0.01(12)$ & $0.3 \pm 0.0(10)$ \\
$\mathrm{Ft}$ & $4.9 \pm 0.10(48)$ & $4.5 \pm 0.1(40)^{*}$ \\
Style & $4.2 \pm 0.20(12)$ & $4.6 \pm 0.2(10)$ \\
\hline
\end{tabular}

No nectar was secreted at the beginning of anthesis (from 18:00 h to 20:00 h), but small amounts were already present early in the morning. Similar volumes were produced in the male and female phases, but concentration of sugars was lower during the latter, when nectar of the first day was removed (table 2).

Table 2. Nectar volume $(\mu \mathrm{L})$ and concentration (sucrose equivalents) in male (day 1) and female (day 2) phases of Ferdinandusa speciosa flowers $(\mathrm{x} \pm \mathrm{SE})$. Accum: nectar accumulated in both phases (see methods). Different letters indicate significant differences.

\begin{tabular}{lcc}
\hline Phase & Volume & Concentration \\
\hline Male $(\mathrm{n}=6)$ & $15.2 \pm 12.1^{\mathrm{a}}$ & $15.5 \pm 1.0^{\mathrm{a}}$ \\
Female $(\mathrm{n}=6)$ & $15.4 \pm 7.1^{\mathrm{a}}$ & $10.8 \pm 1.4^{\mathrm{b}}$ \\
Accum $(\mathrm{n}=15)$ & $18.9 \pm 2.7^{\mathrm{a}}$ & $16.7 \pm 1.1^{\mathrm{a}}$ \\
\hline
\end{tabular}

Floral visitors - Two hummingbird species, Chlorostilbon aureoventris Boucier \& Mulsant, 1848 and Phaethornis pretrei Lesson \& De Lattre, 1839 (figure 2), visited $F$. speciosa flowers. There was visiting activity from $6: 45$ to $17: 45 \mathrm{~h}$, with a peak early in the morning (figure 3 ). $P$. pretrei has a curved bill ( $\mathrm{x}=33.6 \pm 0.7 \mathrm{~mm}$ length, $\mathrm{x} \pm \mathrm{SE}, \mathrm{n}=$ 5), behaved like a trap-liner species (sensu Stiles 1981), and may visit the same flower twice during a visiting bout. The other hummingbird, $C$. aureoventris, has a straight bill ( $\mathrm{x}=19.09 \pm 2.1 \mathrm{~mm}$ length, $x \pm S E, n=5)$ and behaved as a territorialist (sensu Stiles 1981), using a nearby perch between each visiting section. It was not possible to observe exactly which portion of hummingbirds' body contacted anthers and stigma of F. speciosa. However, based on a comparison between bill lengths, floral organs' lengths and visitors' behavior it can be concluded that the contact occurs on the bill for both species, closer to the head for $C$. aureoventris.

Nectar was robbed by Xylocopa sp. and Trigona sp. bees through holes inflicted at the base of the corolla tube. The latter were also observed touching the male and female organs during rare legitimate visits, thus may act as pollinators. Other nectar robbers observed were a species of Nymphalinae in the morning and two Ithomiinae species in the afternoon. These butterflies introduced their proboscis into the entrance but did not contact 


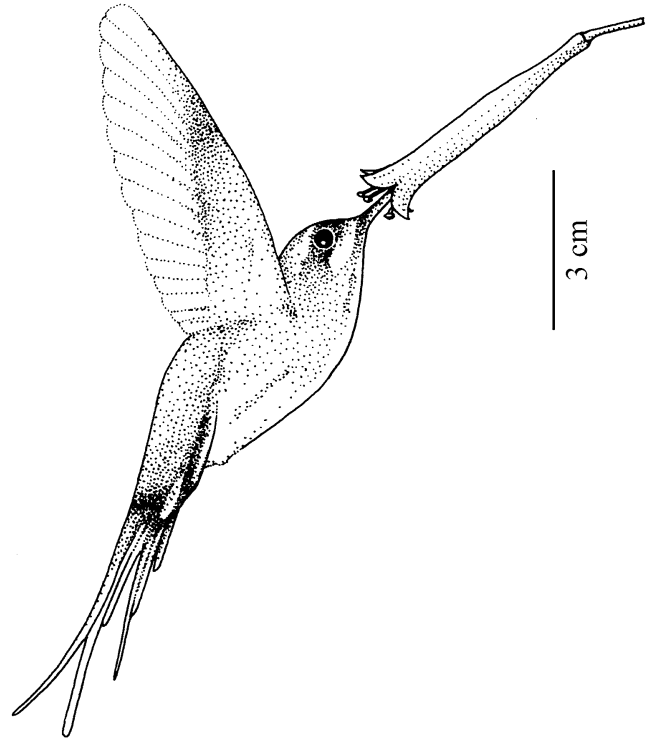

Figure 2. Phaethornis pretrei visiting a flower of Ferdinandusa speciosa.

anthers and stigma during visitation. No visitors were observed after 17:45 $\mathrm{h}$.

Breeding system - F. speciosa is a self-compatible, non-apomitic species, with low fruit production under natural conditions (table 3 ). There were no significant differences between the fruit set of selfand cross-pollinated flowers $\left(\chi^{2}=1.16, \mathrm{P}=0.28\right)$, nor in the pollen tube growth rate after these treatments. Pollen tubes in pistils of both self- and cross-pollinated flowers were observed at the base of the style $24 \mathrm{~h}$ after pollination. However, seeds

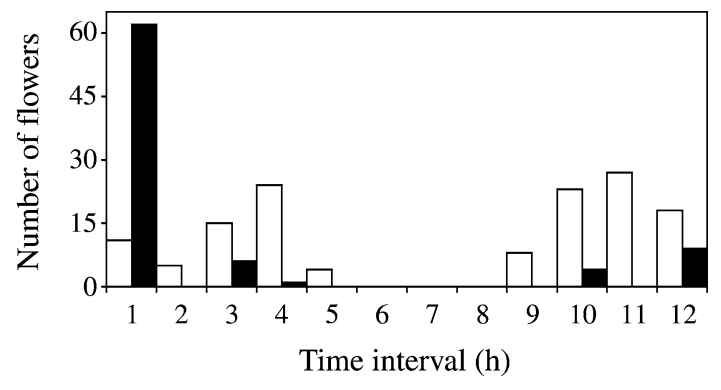

Figure 3. Frequency of visits of the two hummingbird species on flowers of Ferdinandusa speciosa during all the monitored hours. The values on "Time interval (h)" represent intervals of one hour starting at 6:00. White columns: $C$. aureoventris; black columns: P. pretrei.
Table 3. Results of fruit production after hand pollination experiments on flowers of Ferdinandusa speciosa.

\begin{tabular}{lcc}
\hline Experiment & Flowers (n) & Fruits (\%) \\
\hline Self & 35 & 17.1 \\
Cross & 32 & 28.1 \\
Apomixis & 46 & 0.0 \\
Control & 54 & 7.4 \\
\hline
\end{tabular}

resulted from cross-pollination experiments were larger $(\mathrm{H}=5.62, \mathrm{P}=0.018)$, heavier $(\mathrm{H}=41.84$, $\mathrm{P}<0.0001)$ and showed a higher percentage of germination $(\mathrm{t}=-7.59, \mathrm{P}<0.0001)$ than those formed by self-pollination (table 4). After natural (open) pollinations each individual produced a mean of $23.8 \pm 13.3$ fruits $(x \pm S E, n=21)$. The fruits are loculicide capsules (sensu Spjut 1994) which take $c a$. six weeks to develop and to release the wind dispersed seeds.

\section{Discussion}

High daily flower production in some individuals (from 20 to 70) and asynchrony in flowering within individuals, as observed in $F$. speciosa, were also observed by Passos \& Sazima (1995) in Manettia luteorubra (Cinchonineae), another ornithophilous species of Rubiaceae. The inflorescence pulses in $F$. speciosa could not be associated with any particular factor.

Floral biology, morphometrics and floral visitors The terminal inflorescences and the pendent position of the red tubular flowers make them easily accessible for hummingbirds, and corroborate the

Table 4. Fruits and seeds of Ferdinandusa speciosa resulted from experiments. Fruit weight (Fr weight, g), number of seeds per fruit (Seeds/Fruit), seed weight ( $\mathrm{S}$ weight, $\mathrm{g}$ ), seed major length (S length, $\mathrm{mm})$ and seed germination (\% Germin) $(\mathrm{x} \pm \mathrm{SE})$. nt: not tested differences due to small sample size.

\begin{tabular}{lccc}
\hline Atribute & Self $(\mathrm{n})$ & Cross $(\mathrm{n})$ & $\mathrm{P}$ \\
\hline Fr weight & $0.45 \pm 0.1(4)$ & $0.54 \pm 0.1(6)$ & $\mathrm{nt}$ \\
Seeds/Fruit & $13.40 \pm 3.2(4)$ & $12.00 \pm 3.5(6)$ & $\mathrm{nt}$ \\
S weight & $2.79 \pm 0.2(67)$ & $4.49 \pm 0.1(109)$ & $<0.0001$ \\
S length & $1.09 \pm 0.02(67)$ & $1.16 \pm 0.02(109)$ & 0.018 \\
\% Germin & $43.30 \pm 4.9(60)$ & $91.70 \pm 4.0(60)$ & $<0.0001$ \\
\hline
\end{tabular}


syndrome defined by other studies involving hummingbird pollination (Arizmendi \& Ornelas 1990, Sazima et al. 1996). Floral characteristics of $F$. speciosa are markedly similar to those from other tropical species from Rubiaceae like in Manettia luteo-rubra (Passos \& Sazima 1995) and Palicourea petiolaris (Sobrevilla et al. 1983).

Protandry, as registered for F. speciosa, is the dichogamous pattern frequently observed in Rubiaceae, especially in ornithophilous species of tropical forests (Bertin \& Newman 1993). Some authors suggest that dichogamy is a mechanism that may reduce anther-stigma interference (Lloyd \& Webb 1986, Bertin \& Newman 1993). The reduction of interference between male and female organs is almost absolute in $F$. speciosa, due to dichogamy and the spatial separation of male and female structures, caused by the shrivelling of the filaments between the first to the second day. Stamen displacement is a common feature in protandrous species (Lloyd \& Webb 1986). The non-significant difference in style length between male and female phases may have been due to the time of collection of the male flowers used for the measurements. Collected during the afternoon, the styles may have already started to elongate.

The values of volume and sugar concentration in the nectar are similar to other records of hummingbird-pollinated species (Baker 1975, Pyke \& Waser 1981, Cruden et al. 1983, Opler 1983, Sazima et al. 1996). The lower sugar concentration in the nectar of the female phase may be due to changes in the secretion process related to flower senescence (Cruden et al. 1983). Concerning nectar secretion, $F$. speciosa may be classified as a slow producer species (Cruden et al. 1983), because the nectar is accumulated in small amounts at the base of corolla tube. Accumulated nectar of $F$. speciosa shows no reduction in sugar concentration, which would indicate re-absorption.

Breeding system - Although self-compatible, $F$. speciosa seems to be a mostly allogamous species dependent on hummingbirds for pollination. The greater germinability and vigour of seeds from cross-pollination agree with the relatively high pollen: ovule ratio (Cruden 1977) and specialized floral morphology (floral tube, high distance between sexual organs and resource production site), which suggested a priori an outcrossing breeding system. Differences between progenies resulting from self- and cross-pollination are considered consequences, and may be used as estimative of inbreeding depression (Charlesworth \& Charlesworth 1987, Lloyd 1987). Seed weight, size and germinability constitute indicators of progeny quality (Wulff 1995 and references therein).

When fruit production under natural conditions is lower than that obtained by artificial cross-pollination, the former may be interpreted as being pollen limited (Vaughton \& Ramsey 1995). This aspect and the low pollen viability of some individuals suggest that the studied populations receive deficient pollination service. The studied area is a forest remnant nowadays isolated at the outskirts of a fast growing city and subjected to various levels of disturbance. Although hummingbird diversity seems to be still similar to the ones in undisturbed natural areas in the region (G. Oliveira, unpublished data), their populations in the study area may have been affected. Surveys on pollen viability in herbarium material (UEC) of $F$. speciosa from various localities of Brazil suggested that the low viability found in some individuals in the study area is not common and may be another reason for the low fruit-set observed in this study.

The occurrence of protandry in F. speciosa does not agree with the general reproductive patterns suggested by Robbrecht (1988) for the tribe Cinchoneae, which would include heterostyly and secondary pollen presentation. These systems can really be found in the subfamily Cinchonoideae (Bullock 1985, Murray 1990, Passos \& Sazima 1995, Bremer 1996), but they cannot be used as characteristic features defining the group. Other genera of Rubiaceae also show different reproductive strategies than those suggested by Robbrecht (1988). These are the case of Guettarda (Richards \& Koptur 1993), Hamelia (Imbert \& Richards 1993) and Posoqueria (Bawa et al. 1985). The protandry recorded here may be a variation of one of the sexual systems of the Cinchonoideae, probably from secondary pollen presentation, which includes protandry with elongation of the style.

Acknowledgements - We thank the FUTEL-Uberlândia for permission to work in the Parque do Sabiá, M. Ranal for advices during the germination experiments, A. Ruszczyk for the 
identification of the butterflies, S. C. S. Silva e H. P. Neto for help in the field work, M. Sazima and V. Bittrich for comments on the manuscript and E. Kickhöfel for illustrations. Support for this work was provided by $\mathrm{CNPq}$ as a MSc grant for the first author (141402/1997-0) and a research grant for the second author (520872/96-7).

\section{References}

ANDERSSON, L. 1993. A provisional checklist of Neotropical Rubiaceae. Scripta Botanica Belgica 1:5-75.

ARIZMENDI, M.C. \& ORNELAS, J.F. 1990. Hummingbirds and their flower resources in a tropical dry forest in Mexico. Biotropica 22:172-180.

BAKER, H.G. 1975. Sugar concentrations in nectars from hummingbird flowers. Biotropica 7:37-41.

BAWA, K.S. \& BEACH, J.H. 1983. Self-incompatibility systems in the Rubiaceae of a tropical lowland wet forest. American Journal of Botany 70:1281-1288.

BAWA, K.S., PERRY, D.R. \& BEACH, J.H. 1985. Reproductive biology of tropical lowland forest trees. I. Sexual systems and incompatibility mechanisms. American Journal of Botany 72:331-345.

BERTIN, R.I. \& NEWMAN. C.M. 1993. Dichogamy in Angiosperms. Botanical Review 59:112-152.

BREMER, B. 1996. Combined and separate analyses of morphological and molecular data in the plant family Rubiaceae. Cladistics 12:21-40.

BULLOCK, S.H. 1985. Breeding systems in the flora of a tropical deciduous forest in Mexico. Biotropica 17:287-301.

CHARLESWORTH, D. \& CHARLESWORTH, B. 1987. Inbreeding depression and its evolutionary consequences. Annual Review of Ecology and Systematics 18:237-268.

CRUDEN, R.W. 1977. Pollen-ovule ratios: a conservative indicator of breeding systems in flowering plants. Evolution 31:32-46.

CRUDEN, R.W., HERMAN, S.M. \& PETTERSON, S. 1983. Patterns of nectar production and plant-pollination coevolution. In The biology of nectaries (B. Bentley \& T. Elias, eds.). Columbia University Press, New York, p. $80-125$.

DAFNI, A. 1992. Pollination ecology - A practical approach. Oxford University Press, Oxford.

GRANTSAU, R. 1989. Os beija-flores do Brasil. Expressão e Cultura, Rio de Janeiro.

HAMILTON, C.H. 1990. Variations on a dystylous theme in a mesoamerican Psychotria subgenus Psychotria (Rubiaceae). Memoirs of the New York Botanical Garden 55:62-75.

IMBERT, F.M. \& RICHARDS, J.H. 1993. Protandry, incompatibility, and secondary pollen presentation in Cephalanthus occidentalis (Rubiaceae). American Journal of Botany 80:395-404.

INOUYE, D.W., LANUM, J.A., LEVINE, D.M., MEYERS, J.B., ROBERTS, M.S., TSAO, F.C. \& WANG, Y.Y. 1980. The effects of nonsugar nectar constituents on estimates of nectar energy content. Ecology 61:992-996.
KEARNS, C.A. \& INOUYE, D.W. 1993. Techniques for pollination biologists. University Press of Colorado, Niwot.

LLOYD, D.G. 1987. Allocations to pollen, seeds and pollination mechanisms in self- fertilizing plants. Functional Ecology 1:83-89.

LLOYD, D.G. \& WEBB, C.J. 1986. The avoidance interference between the presentation of pollen and stigmas in angiosperms. I. Dichogamy. New Zealand Journal of Botany 24:135-162.

MARTIN, F.N. 1959. Staining and observing pollen tubes in the style by means of fluorescence. Stain Technology 34:125-128.

MURRAY, B.G. 1990. Heterostyly and pollen tube interactions in Luculia gratissima (Rubiaceae). Annals of Botany 65:691-698.

NILSSON, L.A., PETTERSON, B. \& RANAIVO, J. 1990. "Ixoroid" pollen presentation and pollination by small moths in the Malagasy treelet Ixora platythyrsa (Rubiaceae). Plant Systematics and Evolution 170:161-175.

OPLER, P.A. 1983. Nectar production in a tropical ecosystem. In The biology of nectaries (B. Bentley \& T. Elias, eds.). Columbia University Press, New York, p.30-79.

PASSOS, L. \& SAZIMA, M. 1995. Reproductive biology of the distylous Manettia luteo-rubra (Rubiaceae). Botanica Acta 108:309-313.

PYKE, G.H. \& WASER, N.M. 1981. The production of dilute nectar by hummingbird and honeyeater flowers. Biotropica 13:260-270

RADFORD, A.E., DICKSON, W.C., MASSEY, J.R. \& BELL, C.R. 1974. Vascular plant systematics. Harper \& Row Publishers, New York.

REE, R.H. 1997. Pollen flow, fecundity, and adaptative significance of heterostyly in Palicourea padifolia (Rubiaceae). Biotropica 29:298-308.

RICHARDS, J.H. \& KOPTUR, S. 1993. Floral variation and distily in Guettarda scabra L. (Rubiaceae). American Journal of Botany 80:31-43.

ROBBRECHT, E. 1988. Tropical woody Rubiaceae. Opera Botanca Belgica 1:1-271.

SAZIMA, I., BUZATO, S., \& SAZIMA, M. 1996. An assemblage of hummingbird-pollinated flowers in a montane forest in Southeastern Brazil. Botanica Acta 109:149-160.

SOBREVILLA, C., RAMIREZ, N. \& ENRECH, N.X. 1983. Reproductive biology of Palicourea fendleri and $P$. petiolaris (Rubiaceae), heterostylous shrubs of a tropical cloud forest in Venezuela. Biotropica 15:161-169.

SPJUT, R.W. 1994. A systematic treatment of fruit types. Memoirs of the New York Botanical Garden 70:1-182.

STILES, F.G. 1981. Geografical aspects of bird-flower coevolution, with particular reference to Central America. Annals of the Missouri Botanical Garden 68:323-351.

VAUGHTON, G. \& RAMSEY, M. 1995. Pollinators and seed production. In Seed development and germination (J.G.G. Kigel \& G. Galili, eds. and publs.), p.475-490.

WULFF, R.D. 1995. Environmental maternal effects on seed quality and germination. In Seed development and germination (J.G.G. Kigel \& G. Galili, eds. and publs.), p.491-505. 